\title{
Type-specific seroprevalence of bluetongue in India during 2018 and 2019
}

\author{
G. Naresh ${ }^{1}$ (D), Kalyani Putty ${ }^{1}$ (D), Y. Narasimha Reddy ${ }^{1}$ (D) and Y. Krishna Jyothi2 ${ }^{(D)}$
}

1. Department of Veterinary Biotechnology, College of Veterinary Science, P. V. N. R. Telangana Veterinary University, Hyderabad, Telangana, India; 2. Department of Animal Husbandry, Andhra Pradesh Veterinary Biological Research Institute, Vijayawada, Andhra Pradesh, India.

Corresponding author: Kalyani Putty, e-mail: kalyaniputty@gmail.com

Co-authors: GN: gnareshyadav17@gmail.com, YNR: yellanarasimhareddy@gmail.com, YKJ: yadlapatijyothi@yahoo.com Received: 29-01-2020, Accepted: 24-08-2020, Published online: 05-10-2020

doi: www.doi.org/10.14202/vetworld.2020.2092-2096 How to cite this article: Naresh G, Putty K, Reddy YN, Jyothi YK (2020) Type-specific seroprevalence of bluetongue in India during 2018 and 2019, Veterinary World, 13(10): $2092-2096$.

\begin{abstract}
Background and Aim: Bluetongue (BT) is a major disease of sheep and goats and is endemic to India. It is known to cause significant economic losses to the sheep industry. The current study aimed to determine the type-specific seroprevalence of BT in sheep population of India during 2018-2019.
\end{abstract}

Materials and Methods: Blood samples $(n=405)$ were collected from 6 months to 1 year old sheep from six districts (Nalgonda, Karimnagar, Khammam, Mahabubnagar, Warangal, and Ranga Reddy) of Telangana state, India. Group- and type-specific seroprevalence (against BT virus [BTV] serotypes BTV-1, 2, 4, 5, 9, 10, 12, 16, 21, 23, and 24) was studied by competitive enzyme-linked immunosorbent assay and serum neutralization test, respectively.

Results: Results showed an overall seroprevalence of $14.81 \%(\mathrm{n}=60)$ with the highest seroprevalence of $50 \%$ in Khammam district. Seroprevalence of BTV-1, 2, 4, 5, 9, 10, 12, 16, 21, 23, and 24 was noted as $16.66 \%, 11.66 \%, 31.66 \%, 11.66 \%, 05 \%$, $6.66 \%, 16.66 \%, 8.33 \%, 13.33 \%, 6.66 \%$, and $16.66 \%$, respectively. The majority of the sera neutralized more than 1 serotype, indicating superinfection or circulation of multiple serotypes in the sampled flocks. This mixed seroprevalence was observed in $43.33 \%$ of the sera with number of BTV serotype-specific antibodies ranging from two to eight in individual animals.

Conclusion: Regular monitoring of circulating serotypes, especially in young herds, elucidates pattern of dominating serotypes in a particular area during a season. This knowledge can be applied to design appropriate vaccination strategies by including particular serotypes of virus as part of a multivalent vaccine for a particular period, in a particular area.

Keywords: Bluetongue, competitive enzyme-linked immunosorbent assay, serum neutralization test, type-specific seroprevalence.

\section{Introduction}

Bluetongue (BT) is a major Office International Des Epizooties listed disease of sheep and goats and is endemic to India, causing significant economic losses to the sheep industry [1]. It is an insect-borne viral disease of ruminants characterized by inflammation of mucous membranes, congestion, swelling, and hemorrhages. The causative agent is BT virus (BTV) of the genus Orbivirus in the family Reoviridae. The virus is transmitted between vertebrate hosts by Culicoides species $[2,3]$. Outbreaks are frequently reported in the southern states of India, especially during monsoon (JulySeptember) when the activity of the vector is highest and is hence propitious for the occurrence of BT. At present, a total of 29 serotypes of BTV were recognized worldwide [4]. In India, at least 24 serotypes have been identified based on serology and/or virus isolation [5-8]. In

Copyright: Naresh, et al. Open Access. This article is distributed under the terms of the Creative Commons Attribution 4.0 International License (http://creativecommons.org/licenses/ by/4.0/), which permits unrestricted use, distribution, and reproduction in any medium, provided you give appropriate credit to the original author(s) and the source, provide a link to the Creative Commons license, and indicate if changes were made. The Creative Commons Public Domain Dedication waiver (http:// creativecommons.org/publicdomain/zero/1.0/) applies to the data made available in this article, unless otherwise stated.
India, a pentavalent inactivated vaccine containing BTV serotypes BTV-1, 2, 10, 16, and 23 are commercially available (M/S Indian Immunologicals, Hyderabad) for field usage [9].

Infection with multiple serotypes/topotypes of the virus is common in enzootic areas, which makes the control of BT difficult [10]. To design improved prevention and control strategies, it is important to determine the major circulating serotypes of the virus.

With this background, as a first step to reveal type-specific seroprevalence of BT in India during 2018-2019, the present study was undertaken to assess type-specific anti-BTV antibodies in sheep of different parts of Telangana state which rank top in the country in sheep population and also where the disease is rampant with major economic losses experienced. Sheep of age 6 months-1 year were selected for sampling as they represented a group that might have been exposed to only one season of monsoon and, therefore, one season of BT.

\section{Materials and Methods}

\section{Ethical approval}

As per the Committee for the Purpose of Control and Supervision of Experiments on Animals 
guidelines, a study involving collection of clinical samples under field conditions does not require approval of Institute Animal Ethics Committee. Blood samples were collected by licensed veterinarians as per standard sample collection methods without any harm or stress to the animals.

\section{Study area}

Telangana is one of the southern states of India situated between 16 and $20^{\circ}$ latitude and between 77.5 and $81.5^{\circ}$ longitudes and is situated on the Deccan plateau in the central stretch of the eastern seaboard of the Indian Peninsula. It is a semi-arid area and has a predominantly hot and dry climate. Summers start in March and peak in May with average high temperatures in the $42^{\circ} \mathrm{C}\left(108^{\circ} \mathrm{F}\right)-45^{\circ} \mathrm{C}\left(113^{\circ} \mathrm{F}\right)$ range. The monsoon arrives in June and lasts until September with about $755 \mathrm{~mm}$ (29.7 inches) of precipitation. A dry, mild winter starts in late November and lasts until early February with little humidity and average temperatures in the $22-23^{\circ} \mathrm{C}\left(72-73^{\circ} \mathrm{F}\right)$ range. The annual rainfall is between $900 \mathrm{~mm}$ and $1500 \mathrm{~mm}$ in North Telangana and 700 and $900 \mathrm{~mm}$ in South Telangana, from the southwest monsoons.

\section{Collection of sera samples}

The samples were collected during December 2018-March 2019. A total of 405 blood samples were collected from sheep between the ages of 6 months and 1 year from selected villages of six districts (Nalgonda, Karimnagar, Khammam, Mahabubnagar, Warangal, and Ranga Reddy) in Telangana state (Figure-1). The animals belonged to nomadic marginal farmers, were not maintained in organized farms (with no apparent sire and dam data/history), and were not vaccinated with the commercial inactivated pentavalent vaccine of BT. The blood samples were collected in Vacutainer tubes without ethylenediaminetetraacetic acid or heparin. From blood



Figure-1:Overall seroprevalence of bluetongue in different districts of Telangana. Seroprevalence was studied in six districts of Telangana state: Karimnagar, Warangal, Khammam, Nalgonda, Mahabubnagar, and Ranga Reddy. Overall seroprevalence in each district was indicated as percentages in the map [Source: https://www.uokpl.rs/ rsvi/hTboixb_ancient-telangana-tourist/]. samples, sera were separated and stored at $-20^{\circ} \mathrm{C}$ till further use at the Department of Veterinary Biotechnology, College of Veterinary Science, Hyderabad, where all the laboratory tests were performed.

\section{Group-specific seroprevalence of BT}

The test sera were subjected to competitive enzyme-linked immunosorbent assay (c-ELISA) to detect antibodies against the most conserved viral protein, VP7 of BTV, using a commercial kit (Veterinary Diagnostic Technology, Inc., USA). As per the manufacturer's instructions, percentage inhibition values $>50$ were considered as positive. Those that fall between $40 \%$ and $55 \%$ were suggested to be retested. Two samples of the total sampled in the current study were in the retest range $(45 \%)$. Those on retesting remained in the negative result group.

\section{Type-specific seroprevalence of BT}

Plaque purified viruses BTV-1, 2, 4, 5, 9, 10, 12, $16,21,23$, and 24 were used in the serum neutralization assay for detecting serotype-specific antibodies. These viruses were the only BTV isolates available with us and were isolated from previous BT outbreaks in the state (unpublished data). Hyperimmune sera against each of the plaque purified BTV serotypes were used as positive controls with no apparent cross-reactivity between serotypes. Hyperimmune sera for the tested BTV serotypes were raised by us previously as follows: BTV seronegative Deccani sheep (6-8 months) were shifted to insect proof experimental animal house. After deworming and acclimatization, $1 \mathrm{ml}$ of $10^{6} / \mathrm{ml} \mathrm{TCID50}$ virus was inoculated to sheep by two routes, that is, $0.5 \mathrm{ml}$ through intradermal and $0.5 \mathrm{ml}$ through subcutaneous routes at shoulder region. On the $15^{\text {th }}$ day of infection, one more injection of same dose was given to the animals. Serum samples were collected on $0,7,14,21$, and 28 days post-inoculation to assess the antibodies level and seroconversion. For type-specific seroprevalence, the SNT method was as follows: $50 \mu \mathrm{l}$ consisting of $100 \mathrm{TCID}_{50}$ of individual BTV serotype was incubated with $50 \mu 1$ of 1:20 diluted serum for $1 \mathrm{~h}$ at $37^{\circ} \mathrm{C}$. The serum-virus mixture was then inoculated on to confluent Vero cell monolayers in tissue culture plates, in quadruplicate. Cells were observed for cytopathic changes for 5 days at $24 \mathrm{~h}$ interval. After 5 days, the culture plates were fixed with $10 \%$ formaldehyde and stained with $1 \%$ crystal violet (HiMedia, Mumbai). Wells with 25-100\% staining were considered to have no or limited continuing professional education (CPE) (i.e., positive for neutralization). Wells with $<25 \%$ staining were considered to have extensive or full CPE (i.e., negative for neutralization).

\section{Results}

\section{Group-specific seroprevalence of BT}

The sera were first screened by c-ELISA for the detection of BTV group-specific antibodies. Out of 405 serum samples, 60 were found positive for BTV 
Table-1: Type-specific seroprevalence of BTV.

\begin{tabular}{|c|c|c|c|}
\hline S. no. & Districts & c-ELISA positive $\%$ & Prevalent BTV serotypes \\
\hline 1. & Nalgonda & $10.83(13 / 120)$ & $1,2,4,5,10,12,16,21,23$, and 24 \\
\hline 2. & Karimnagar & $26(13 / 50)$ & $1,2,4,5,12,16,23$, and 24 \\
\hline 3. & Khammam & $50(25 / 50)$ & $1,2,4,5,9,10,12,21$, and 24 \\
\hline 4. & Mahabubnagar & $05(2 / 40)$ & $1,2,4,5,9,12,16,21$, and 24 \\
\hline 5. & Warangal & $0(0 / 45)$ & -------- \\
\hline \multirow[t]{2}{*}{6.} & Ranga Reddy & $07(7 / 100)$ & $4,5,12,21$, and 24 \\
\hline & Total & $14.81 \%(60 / 405)$ & 11 serotypes \\
\hline
\end{tabular}

$\mathrm{BTV}=$ Bluetongue virus, $\mathrm{c}-\mathrm{ELISA}=$ Competitive enzyme-linked immunosorbent assay

Table-2: Number and types of mixed serotype seroprevalences observed in Telangana state, India, during 2018-2019.

\begin{tabular}{|c|c|c|}
\hline S. no. & $\begin{array}{l}\text { Number } \\
\text { serotypes }\end{array}$ & BTV serotype combinations \\
\hline 1. & $\begin{array}{l}\text { Two } \\
\text { serotypes }\end{array}$ & $\begin{array}{l}\text { BTV- } 1 \text { and } 2,1 \text { and } 4,1 \text { and } 9,2 \\
\text { and } 21,4 \text { and } 5,4 \text { and } 12,4 \text { and } \\
24,9 \text { and } 12,9 \text { and } 24,10 \text { and } 23, \\
12 \text { and } 21\end{array}$ \\
\hline 2. & $\begin{array}{l}\text { Three } \\
\text { serotypes }\end{array}$ & $\begin{array}{c}\text { BTV-5, 21, and } 24 ; 10,16 \text {, and } 23 ; \\
\text { 12, 16, and 23; 1, 4, and 24; } \\
2,4 \text {, and } 24\end{array}$ \\
\hline 3. & $\begin{array}{l}\text { Four } \\
\text { serotypes }\end{array}$ & $\begin{array}{c}\text { BTV-1, 2, 4, and 24; 1, 2, 4, and 5; } \\
4,10,12 \text {, and } 21\end{array}$ \\
\hline 4. & $\begin{array}{l}\text { Five } \\
\text { serotypes }\end{array}$ & BTV-10, 12, 16, 21, and 23 \\
\hline 5. & Six serotypes & BTV-1, 2, 4, 5, 21, and 23 \\
\hline 6. & $\begin{array}{l}\text { Eight } \\
\text { serotypes }\end{array}$ & BTV-1, 2, 4, 5, 12, 16, 21, and 24 \\
\hline
\end{tabular}

$\mathrm{BTV}=$ Bluetongue virus

group-specific antibodies giving a positive percentage of $14.81 \%$. The seropositivity of BTV in the sheep was $10.83 \%, 26.0 \%, 50.0 \%, 5.0 \%, 0 \%$, and $7.0 \%$ for Nalgonda, Karimnagar, Khammam, Mahabubnagar, Warangal, and Ranga Reddy districts of Telangana state, respectively (Figure-1).

\section{Type-specific seroprevalence of BT}

c-ELISA-positive samples were screened for type-specific neutralizing antibodies against BTV serotypes BTV-1, 2, 4, 5, 9, 10, 12, 16, 21, 23, and 24. Out of the 60 positive sera, $19(31.66 \%)$ showed antibodies against BTV-4, which was highest for the study period, followed by $10(16.66 \%)$ to BTV-1, -12 , and -24 each. Further, 8 (13.33\%) were positive for BTV-21; 7 $(11.66 \%)$ for BTV-2 and -5 each; $5(8.33 \%)$ for BTV$16 ; 4(6.66 \%)$ for BTV-10 and -23 each, and $3(5 \%)$ to BTV-9 (Table-1). Mixed seroprevalence with each individual animal harboring BTV antibodies raised against more than one viral serotype was observed in $43.33 \%$ of BTV group-specific seropositive animals. The number of serotypes varied from two to eight with a variety of serotype combinations (Table-2).

\section{Discussion}

BTV seroprevalence of varying percentages was reported by several authors before [11-17]. In BT endemic countries such as India, high seroprevalence $(>50 \%)$ is usually reported [18-22]. Especially, in the tested region included in the present study, the previous studies reported $61 \%$ seroprevalence of BTV during 2005-2009 and 75\% during 2014$2017[5,23,24]$. Here, we report a comparatively low seroprevalence of BTV than was reported before. Such low rates (9.3-18.4\%) were also reported by other researchers[25-27]. A huge variation between the findings of various authors regarding seroprevalence of BTV among small ruminants in various states of India may be due to varied climatic conditions, sheep population density, and susceptibility of sheep breeds to BT. In the current study, age (6 months- 1 year old) of the sheep selected might have played a major role in the results observed. Young animals have a lesser probability of exposure to BTV infection as they would have been exposed to fewer monsoon seasons where peak Culicoides activity is noticed. In spite of this reason, young animals were chosen in the study to identify the circulating serotypes in the current season. This could also be a major reason in $0 \%$ BTV seroprevalence found in one of the districts included in the current study. Attempts at isolating BTV from the samples collected were not successful (data not shown), probably because blood was collected from apparently healthy animals which might have had exposure to BTV infection much earlier and viremia cleared before the samples were collected. In the current study, only one dilution $(1: 20)$ of the test serum was used in the neutralization assay. Titration of antibodies was not done in the present study as our main aim was to identify the circulating serotypes of BTV. However, serotype titer ranges (low, medium, or high) per area would have provided a better understanding of the infection severity and seroprevalence in the tested region.

India being endemic to BT, it is not uncommon to find such mixed serotype seroprevalence [5]. This indicates superinfection or circulation of multiple serotypes in the sampled flocks, which reflected in the multiserotype virus isolation from individual BT suspected animals [6]. In Telangana state specifically, a vast variation in the serotype prevalence over the past decade in different livestock hosts was previously observed $[5,23,24,28]$ (summarized in Table-3). On comparison, it can be noted that, during 2005-2009, seroprevalence of BTV-1 and 2 was high; seroprevalence of BTV-16, 21, and 9 was dominant during 2014 
Table-3: Type-specific seroprevalence of BTV in various regions during different periods in India.

\begin{tabular}{|c|c|c|c|}
\hline S. No. & Region & Species & Prevalence \\
\hline 1. & Andhra Pradesh and Telangana (2005-2009) [5] & Sheep & $\begin{array}{c}50.0 \% \text { of BTV-1 } \\
44.23 \% \text { of BTV-2 } \\
26.92 \% \text { of BTV-10 } \\
21.25 \% \text { of BTV-9 } \\
15.38 \% \text { of BTV- } 23 \\
0 \% \text { of BTV- } 21\end{array}$ \\
\hline 2. & Andhra Pradesh and Telangana (2014-2015) [23] & Sheep, goat, and calf & $\begin{array}{l}70 \% \text { of BTV }-16 \\
30 \% \text { of BTV- } 21 \\
25 \% \text { of BTV-9 } \\
12.5 \% \text { of BTV-2 } \\
7.5 \% \text { of BTV-10 } \\
2.5 \% \text { of BTV-23 }\end{array}$ \\
\hline 3. & Andhra Pradesh and Telangana (2015-2016) [23] & $\begin{array}{l}\text { Sheep, goat, buffalo, and } \\
\text { cattle }\end{array}$ & $\begin{array}{c}25.5 \% \text { of BTV- } 23 \\
18 \% \text { of BTV }-1 \\
17.4 \% \text { of BTV- } 16 \\
11.1 \% \text { of BTV-2 } \\
6.2 \% \text { of BTV- } 21 \\
4.3 \% \text { of BTV- } 12 \\
2.5 \% \text { of BTV- }-4 \\
1.2 \% \text { of BTV- } 9\end{array}$ \\
\hline 4. & Andhra Pradesh and Telangana (2016-2017) [24] & Sheep and goat & $\begin{array}{c}40.62 \% \text { of BTV-2 } \\
34.37 \% \text { of BTV-1 } \\
28.12 \% \text { of BTV- } 4 \text { and } 16 \\
25 \% \text { of BTV- } 24 \\
9.37 \% \text { of BTV-23 } \\
6.25 \% \text { of BTV- } 9 \text { and } 12 \\
3.12 \% \text { of BTV- } 21\end{array}$ \\
\hline 5. & Tripura (2014-2017) [28] & Goats & $\begin{array}{c}65.27 \% \text { of BTV-1 } \\
26.38 \% \text { of BTV-16 } \\
20.83 \% \text { of BTV-10 } \\
13.88 \% \text { of BTV- } 9 \text { and } 23 \\
6.94 \% \text { of BTV-2 }\end{array}$ \\
\hline 6. & Telangana (2018-2019) [Current study] & Sheep & $\begin{array}{c}31.66 \% \text { of BTV }-4 \\
16.66 \% \text { of BTV }-1,12 \text { and } 24 \\
13.33 \% \text { of BTV- } 21 \\
11.66 \% \text { of BTV- } 2 \text { and } 5 \\
8.33 \% \text { of BTV- } 16 \\
6.66 \% \text { of BTV }-10 \text { and } 23 \\
5.0 \% \text { of BTV-9 }\end{array}$ \\
\hline
\end{tabular}

BTV=Bluetongue virus

and 2015; BTV-23, 1, and 16 during 2015-16; BTV2, 1 , and 4 during 2016-2017; and during 2018-2019, seroprevalence of BTV-4, 1, 12, and 24 was high (summarized in Table-3). Meanwhile, in the Northeastern part of India, during 2014-2017, type-specific seroprevalence of BTV-1, 16, and 10 was reported in high rates in goats. It is interesting to note from these findings, emergence of serotypes not included in the commercial pentavalent inactivated BT vaccine (harboring BTV-1, 2, 10, 16, and 23), that is, BTV-4, 9, 12,21 , and 24.

\section{Conclusion}

The current study indicates that BTV circulation is widespread in Telangana state of India. We have also observed seroprevalence of different BTV serotypes along with the presence of multiple seroprevalences in individual animals. In comparison with the previous reports, it may be concluded that different BTV serotypes were predominant during different periods in a particular region, along with the presence of mixed serotype prevalences. Surveillance programs based on seromonitoring can help forecast possible future outbreaks. For establishing effective control strategies like vaccination, extensive surveillance in different regions of the country is crucial.

\section{Authors' Contributions}

KP and YNR supervised, designed, and coordinated the study. GN and YKJ collected samples and performed the experiments. KP, and YNR analyzed the data. KP and YKJ wrote the manuscript. All authors read and approved the final manuscript.

\section{Acknowledgments}

The authors acknowledge "ICAR-All India Network Programme on Bluetongue" for the financial support.

\section{Competing Interests}

The authors declare that they have no competing interests. 


\section{Publisher's Note}

Veterinary World remains neutral with regard to jurisdictional claims in published map and institutional affiliation.

\section{References}

1. OIE. (2018) Animal Health in the World, OIE-listed Diseases, Infections and Infestations in Force in 2018. OIE, Paris, France.

2. Mellor, P.S. and Wittmann, E.J. (2002) Bluetongue virus in the Mediterranean Basin 1998-2001. Vet. J., 164(1): 20-37.

3. Sperlova, A. and Zendulkova, D. (2011) BT: A review. Vet. Med. Czech, 56(9): 430-452.

4. Maan, S., Maan, N.S., Belaganahalli, M.N., Potgieter, A.C., Kumar, V., Batra, K. and Mertens, P.P. (2016) Development and evaluation of real-time RT-PCR assays for detection and typing of bluetongue virus. PLoS One, 11(9): e0163014.

5. Sairaju, V., Susmitha, B., Rao, P.P., Hegde, N.R., Meena, K. and Reddy, Y.N. (2013) Type-specific seroprevalence of bluetongue in Andhra Pradesh, India, during 2005-2009. Indian J. Virol., 24(3): 394-397.

6. Hemadri, D., Maan, S., Chanda, M.M., Rao, P.P., Putty, K. Krishnajyothi, Y. and Maan, N.S. (2017) Dual infection with bluetongue virus serotypes and first-time isolation of serotype 5 in India. Transbound. Emerg. Dis., 64(6): 1912-1917.

7. Krishnajyothi, Y., Maan, S., Kandimalla, K., Maan, N.S., Tutika, R.B., Reddy Y.V. and Ahmed, S.M. (2016) Isolation of BT virus 24 from India-an exotic serotype to Australasia. Transbound. Emerg. Dis., 63(4): 360-364.

8. Maan, S., Maan, NS., Belaganahalli, M., Kumar, A., Batra, K., Rao, P.P., Hemadri, D., Reddy, Y.N., Putty, K., Yadlapati, K.J., Reddy, G.H., Singh, K.P., Hegde, N.R., Nomikou, K., Daggupati, S. and Mertens, P.P.C. (2015) Genome sequence of bluetongue virus Type 2 from India: Evidence for reassortment between outer capsid protein genes. Genome Announc., 3(2): e00045.

9. Reddy, Y.K., Manohar, B., Pandey, A.B., Reddy, Y.N., Prasad, G. and Chauhan, R.S. (2010) Development and evaluation of inactivated pentavalent adjuvanted vaccine for Bluetongue. Indian Vet. J., 87(5): 434-436.

10. Reddy, Y.V., Krishnajyothi, Y., Susmitha, B., Devi, B.V., Brundavanam, Y., Gollapalli, S.R. and Sunitha, G. (2016) Molecular typing of bluetongue viruses isolated over a decade in South India. Transbound. Emerg. Dis., 63(5): e412-e418.

11. Ozgunluk, I. (2009) A serologic investigation of blue tongue virus serotypes BTV-9, BTV16 in cattle in the Southeastern Anatolia project area in Turkey. J. Anim. Vet. Adv., 8(12): 2613-2616.

12. Mohammadi, A., Tanzifi, P. and Nemati, Y. (2012) Seroepidemiology of bluetongue disease and risk factors in small ruminants of Shiraz Suburb, Fars Province, Iran. Trop. Biomed., 29(4): 632-637.

13. Halder, A., Joardar, S.N., Isore, D.P., Samanta, I., Parui, P., Banerjee, D. and Lodh, C. (2016) Seroepidemiology of bluetongue in South Bengal. Vet. World, 9(1): 1.

14. Sharma, R.N., Beckford, S., Tiwari, K., Vinet, E., Thomas, D., de Allie, C. and Chikweto, A. (2016a) Seroprevalence of BT virus antibody in ruminants from
Grenada. Open J. Vet. Med., 6(6): 99.

15. Gordon, S.J., Bolwell, C., Rogers, C.W., Musuka, G., Kelly, P., Guthrie, A. and Hamblin, C. (2017) A serosurvey of bluetongue and epizootic haemorrhagic disease in a convenience sample of sheep and cattle herds in Zimbabwe. Onderstepoort J. Vet. Res., 84(1): 1-5.

16. Da Silva, T.G., Lima, M.S., Spedicato, M., Carmine, I., Teodori, L., Leone, A. and De Stefano, E. (2018) Prevalence and risk factors for bluetongue in the state of São Paulo, Brazil. Vet. Med. Sci., 4(4): 280-287.

17. Hwang, J.M., Kim, J.G. and Yeh, J.Y. (2019) Serological evidence of bluetongue virus infection and serotype distribution in dairy cattle in South Korea. BMC Vet. Res., 15(1): 255 .

18. Raut, S.D., Deshmukh, V.V. and Aziz, A. (2013) Prevalence of antibodies to bluetongue virus in large ruminants of Marathwada region of Maharashtra state. Vet. World, 6(7): 416-418.

19. Didugu, H., Sagi, S. and Reddy, N. (2015) Seroprevalence of bluetongue virus in small ruminants of Krishna District, Andhra Pradesh, India by competitive Elisa. J. Anim. Res., 5(4): 939

20. Ayanur, A., Singh, K.P., Cherian, S., Singh, V., Nandi, S., Saminathan, M. and Tiwari, A.K. (2016) Sero-epidemiology and molecular detection of bluetongue virus in Indian ruminants. Vet. Ital., 52(3-4): 305-311.

21. Maan, S., Tiwari, A., Chaudhary, D., Dalal, A., Bansal, N., Kumar, V., Batra, K., Kumar, A., Kakker, N. and Maan, N.S. (2017) A comprehensive study on seroprevalence of BT virus in Haryana state of India. Vet. World, 10(12): 1464-1470.

22. Karam, A., Puro, K., Das, S., Shakuntala, I., Sanjukta, R., Milton, A.A.P. and Sen, A. (2018) Seroprevalence of peste des petits ruminants and bluetongue in goat population of Meghalaya, India. Vet. World, 11(12): 1689.

23. Indian Council of Agriculture Research. (2014-2016) Annual Report, All India Network Project on BT. Indian Council of Agriculture Research, New Delhi, India.

24. Indian Council of Agriculture Research. (2016-2017) Annual Report, All India Network Project on BT. Indian Council of Agriculture Research, New Delhi, India.

25. Bulut, O., Yavru, S.İ.B., Yapkic, O.R.H., Simsek, A., Kale, M.E.H. and Avci, O.Ğ.U. (2006) Serological investigation of bluetongue virus infection by serum neutralization test and ELISA in sheep and goats. Bull. Vet. Inst. Pulawy, 50(3): 305.

26. Arun, S., John, K., Ravishankar, C., Mini, M., Ravindran, R. and Prejit, N. (2014) Seroprevalence of bluetongue among domestic ruminants in Northern Kerala, India. Trop. Biomed., 31(1): 26-30.

27. Sohail, T., Yaqub, T., Abbas, T., Rabbani, M., Nazir, J., Maqbool, S.M. and Zahoor, M.Y. (2019) Seroprevalence of bluetongue virus in small and large ruminants in Punjab Province, Pakistan. Acta. Trop., 189(2019): 22-29.

28. De, A., Das, T.K., Chand, K., Debnath, B.C., Dey, S., Hemadri, D. and Tewari, N. (2019) Seroprevalence of BT and presence of viral antigen and type-specific neutralizing antibodies in goats in Tripura, a state at Indo-Bangladesh border of Northeastern India. Trop. Anim. Health Prod., 51(1): 261-265. 